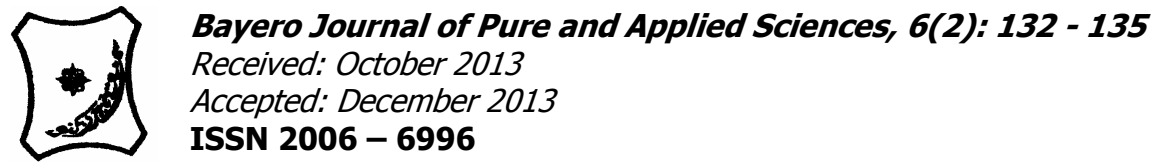

\title{
LENGTH -WEIGHT RELATIONSHIP AND CONDITION FACTOR IN THE POLYCULTURE OF CLARIAS AND TILAPIA IN CONCRETE TANKS
}

\author{
${ }^{* 1}$ Haruna, M. A. and ${ }^{2}$ Ipinjolu, J.K. \\ ${ }^{1}$ Department of Forestry, Fisheries and Wildlife, Kano University of Science and Technology, Wudil.P.M.B. 3244, \\ Kano State, Nigeria. \\ ${ }^{2}$ Department of Forestry and Fisheries, UsmanuDanfodiyo University, P.M.B. 2346, Sokoto, Nigeria. \\ (*Correspondence author;auwal3@yahoo.com)
}

\begin{abstract}
The experiment was conducted to determine the length weight relationship and condition factor of Clariasgariepinus and Oreochromisniloticus in five different stocking combinations for a period of twelve weeks from $17^{\text {th }} \mathrm{July}-9^{\text {th }}$ October, 2009. A total of 1,509 juveniles of C. gariepinus with average weight of $24.88 \mathrm{~g}$ and average length of $14.52 \mathrm{~cm}$, and 2,991 juveniles of 0 . niloticus with average weight of $24.90 \mathrm{~g}$ and average length of $10.93 \mathrm{~cm}$ were stocked at $30 \mathrm{fish} / \mathrm{m}^{2}$ in clarias:tilapia ratios of 0:1, 1:0, 1:2, 1:4, and 1:6. The fish were fed at 3\% body weight per day (BWD) over a period of 84 days. The monoculture of the two species (Treatments 1 and 2) yielded the lowest growth indices (WG, \%WG and SGR), while the performance of clarias at each of the three polyculture systems were higher than those of tilapia. For clarias Treatment 5 (1:6) had the maximum length $(17.92 \pm 0.37 \mathrm{~cm})$ while the monoculture recorded the minimum of 16.60 0.29 . The monoculture of tilapia gave the lowest length gain $(4.83 \pm 0.41 \mathrm{~cm})$ while the highest $(11.60 \pm 0.51 \mathrm{~cm})$ for tilapia was recorded in Treatment $4(1: 4)$. From the regression parameters and the associated statistics ( $r$ and SE) for the validation of the models, it is evident that there was a strong positive relationship between length and weight. Even though the relationship was curvilinear there were still higher percentages of regression coefficient in all the treatments and between the species. The SE was also low in all the treatments which further validated the log transformed models. Therefore, the models are valid for estimating weight of the fishes from the length measurements without necessarily measuring the weight. Stocking ratio of 1:6 should be encouraged for better growth performance.
\end{abstract}

Keywords: Polyculture, length - weight, condition factor, clarias, tilapia, juveniles.

\section{INTRODUCTION}

Various factors may be responsible for differences in length-weight relationships of fish. Some of these factors are sex, stage of maturity, season and time of the day (Bagenel and Tesch, 1978). King (1996) also observed that temperature, salinity, food (quality, quantity and size), time of the day/year and stage of maturity are responsible for differences in lengthweight relationship. Length-weight relationship (LWR) is of great importance in fishery assessments (Garcia et al. 1998; Haimovici and Velasco, 2000). Length and weight measurements in conjunction with age data can give information on the stock composition, age at maturity, life span, mortality, growth and production (Beyer, 1987; King, 1996 and Diaz et al., 2000). Frota et al. (2004) reported that the parameter ' $b$ ' of the length-weight relationship equation $\left(W=a^{b}\right)$, also known as allometry coefficient has an important biological meaning, indicating the rate of weight gain relative to growth in length. The author noted that marked variability in estimates of ' $b$ ' is observed among different groups of the same population at different times. King (1996) observed that the marked variability in the value of ' $b$ ' may reflect changes in the condition of individual related to feeding, reproductive or migratory activities. The aim of this study was to determine the effect of stocking ratio on growth performance in the polyculture of $C$. gariepinusand $O$. niloticus in concrete tanks.

\section{MATERIALS AND METHODS}

The Study Area

The study was conducted at Khasu integrated farm located at $15 \mathrm{~km}$ along Kano - Madobi Road in Kumbotso Local Government Area of Kano State. The study area lies between latitudes $11^{\circ} 20^{\prime}$ and $11^{\circ} 45^{\prime}$ North and longitudes $8^{\circ} 15^{\prime}$ and $8^{0} 30^{\prime}$ East.

Experimental Fish

A total of one thousand five hundred and nine juveniles of Clariasgariepinus (average body weight $24.88 \mathrm{~g}$ and average body length of $14.52 \mathrm{~cm}$ ) were obtained from A4 Global fisheries, Karkasara Road, behind Aminu Kano Teaching Hospital, Kano. Also two thousand nine hundred and ninety one juveniles of $O$. niloticus (average body weight of $24.90 \mathrm{~g}$ and average body length of $10.93 \mathrm{~cm}$ ) were obtained from Bagauda Fish Seed Multiplication Centre, Kano, Nigeria. A total of four thousand five hundred experimental fish were used for the study from $17^{\text {th }}$ July $-9^{\text {th }}$ October, 2009.

\section{Pond Preparation}

The study was conducted using fifteen concrete tanks of $(2 \times 5 \times 1.2 \mathrm{~m})$ sizes in triplicate.Prior to stocking, ponds were drained, washed and filled with water from the reservoir to a depth of $1.0 \mathrm{~m}$. 
Both the inlet and outlet were screened to prevent incoming of unwanted organisms and escape of fish, respectively. Water levels in all the treatments were maintained by changing the water weekly. The water quality parameters measured included dissolved oxygen (DO), hydrogen ion concentration $(\mathrm{pH})$ and temperature $\left({ }^{0} \mathrm{C}\right)$

\section{Experimental Design}

The fishes were acclimatized for a period of fourteen days and five treatments were randomly allocated to the tanks in triplicate. The experiment was laid out in a Completely Randomised Block Design (RCBD). Fifteen tanks of $2 \mathrm{~m} \times 5 \mathrm{~m} \times 1.2 \mathrm{~m}$ sizes were stocked at $30 \mathrm{fish} / \mathrm{m}^{3}$. The treatments comprised of the following clarias:tilapia stocking ratios ; (T1) 300 Tilapia only, (T2) 300 Clarias only, (T3) 100:200, (T4) 60:240 and (T5) 43:257. The experiment lasted for 84 days.

\section{Feeding Rate and Frequency}

Fish in all the treatments were fed experimental diet (Multifeed, 2mm) containing 45\% crude protein, at $3 \%$ body weight per day (BWD). Feeding rate was adjusted weekly based on weight gain and the feeding frequency in all the treatments was twice daily. The total feed fed per day was divided into two, one part was fed in the morning around (9:00am) and the second part in the evening at (5:00pm).

\section{Data Collection}

All fishes were weighed individually at the beginning and end of the experiment, while one third of the population was sampled weekly to monitor growth performance. Length measurement was carried out to the nearest centimeters using a measuring board graduated in centimeters. Total length ( $T L$ ) was measured from the anterior most extremity of the fish to the end of the caudal fin. The total weight was measured in grams using Ohaus electric balance of $310 \mathrm{~g}$ capacity.

\section{Water Quality Monitoring}

The parameters monitored on a weekly basis were dissolved oxygen (DO), hydrogen ion concentration $(\mathrm{pH})$ and temperature at 8:00am adopting the method of Boyd (1979). Temperature was measured with a simple centigrade mercury thermometer. The pHwas done with Jenway $\mathrm{pH}$ meter while the dissolved oxygen level was determined according to Winkler's method.

\section{Statistical Analysis}

Data collected were subjected to analysis of variance (ANOVA) to test the effect of different stocking ratios on growth performance of clarias and tilapia. Where there was significant difference, the means were separated using Duncan's Multiple Range Test at 0.05 probability level. Regression analysis was used to establish the length-weight relationships with the aid of Statistical Package for Social Scientists (SPSS) version 12.

\section{RESULTS}

Weight and length were measured weekly for a period of 12 weeks as the baseline for growth increment determination. The results in Table 1 present the regression coefficients in terms of species and treatments with the following model forms:

Table 1: Regression coefficients of Tilapia and Clarias in the polyculture system

\begin{tabular}{lllllll}
\hline Treatment & $\mathbf{n}$ & $\mathbf{a}$ & $\mathbf{b}$ & $\mathbf{S E}$ of $\mathbf{a}$ & SE of b & $\mathbf{r}$ \\
\hline Trt 1 Tilapia & 1500 & -0.776 & 1.819 & 0.192 & 0.076 & 0.53 \\
Trt 2 Clarias & 1500 & -3.863 & 2.668 & 0.029 & 0.010 & 0.99 \\
Trt 3 Tilapia & 997 & -5.119 & 3.496 & 0.054 & 0.021 & 0.98 \\
Trt 3 Clarias & 496 & 0.359 & 1.272 & 0.186 & 0.064 & 0.67 \\
Trt 4 Tilapia & 1200 & -1.846 & 2.223 & 0.131 & 0.051 & 0.79 \\
Trt 4 Clarias & 300 & -3.916 & 2.674 & 0.663 & 0.021 & 0.99 \\
Trt 5 Tilapia & 1287 & 1.986 & 0.776 & 0.064 & 0.025 & 0.65 \\
Trt. 5 Clarias & 211 & -4.071 & 2.740 & 0.168 & 0.055 & 0.96 \\
\hline
\end{tabular}

$a, b=$ regression parameters of estimate; $r=$ correlation coefficient; $S E=$ standard error; $n=$ number of fish.

$\log \mathrm{W}=\mathrm{a}+$ blogL (tilapia)

$\log W=a+$ blogL (clarias)

$\log \mathrm{W}=\mathrm{a}+$ blogL (treatments)

The values obtained for the length weight relationship showed that Treatment 2 (clarias), Treatment 3 (tilapia), Treatment 4 (clarias) and Treatment 5 (clarias) with ' $b$ ' values ranging from $2.6-3.4$; exhibited isometric pattern of growth while other treatments with ' $b$ ' values of $0.78-1.82$ were allometric in their growth.

Table 2 presents length growth parameters of $C$. gariepinus and $O$. niloticus. For clarias Treatment $5(1: 6)$ had maximum length growth performance $(17.92 \pm 0.37 \mathrm{~cm})$ while the monoculture recorded the minimum $(16.60 \pm 0.29 \mathrm{~cm})$ with more than $1 \mathrm{~cm}$ less than the highest value. The monoculture of tilapia gave the lowest length gain $(4.83 \pm 0.41 \mathrm{~cm})$ while the highest length gain $(11.60 \pm 0.51 \mathrm{~cm})$ for tilapia was recorded in Treatment 4 (1:4).In terms of the percentage length gain, Treatment 5 (1:6) recorded the highest $(P<0.05) 123.30 \pm 2.26$ and the lowest $115.53 \pm 1.83$ was recorded in Treatment $3(0: 1)$ for clarias within 12 weeks. For tilapia the highest percentage length gain $(109.69 \pm 9.44)$ was recorded in Treatment $4(1: 4)$ and the lowest $(45.62 \pm 5.90)$ in Treatment $1(0: 1)$. 
\begin{tabular}{l} 
Table 2: Length growth parameters of $C$. gariepinus and 0 . niloticus in a polyculture system \\
\hline Parameter Trt 1(0:1) Trt 2(1:0) $3(1: 2)$
\end{tabular}

IML(cm) $10.64 \pm 0.45(1500) \quad 14.35 \pm 0.33(1500)$

Clarias

Trt 3 (1:2)

$$
\text { Tilapia }
$$

Clarias

(30)

Trt 4 (1:4)

$14.47 \pm 0.25(300$

$\mathrm{FML}(\mathrm{cm})$

$15.47 \pm 0.11^{9}$

$30.96 \pm 0.05^{c}$

$14.5 \pm 0.10(496)$
$31.25 \pm 0.05^{c}$

$10.50 \pm 0.39$ (997)

$\mathrm{LG}(\mathrm{cm})$

$4.83 \pm 0.41^{\mathrm{f}}$

$16.60 \pm 0.29^{\mathrm{b}}$

$16.75 \pm 0.15^{\mathrm{b}}$

$17.05 \pm 0.05$

$6.54 \pm 0.37^{\mathrm{e}}$

$31.55 \pm 0.01^{\mathrm{b}}$

$17.08 \pm 0.26^{\mathrm{b}}$

$115.53 \pm 1.83^{\mathrm{ab}} \quad 62.45 \pm 5.92^{\mathrm{d}}$

$118.13 \pm 3.88^{\mathrm{ab}}$

$$
\text { Tilapia }
$$

Tilapia

$10.60 \pm 0.43(1200)$
$22.21 \pm 0.10^{d}$
$11.60 \pm 0.51^{c}$

$0.51^{c}$

$109.69 \pm 9.44^{b}$

IML = initial mean length; FML = final mean length; $W G=$ length gain

As presented in Table 3 clarias outweighed tilapia in terms of weight gain. Treatment 5 gave the best result in terms of weight gain for both clarias $(236.20 \pm 3.20)$ and tilapia (105.65 \pm 3.95$)$ while the minimum weight gain was recorded for tilapia monoculture in Treatment $1(69.28 \pm 0.85)$ and $(186.34 \pm 1.28)$ for Clarias in Treatment 2.The monoculture of the two species (Treatments 1 and 2) yielded the lowest growth indices (WG, \%WG and SGR), while the performance of Clarias at each of the three polyculture systems were higher than those of tilapia. This indicated increased growth performance of the tilapia with increased ratio of Clarias to be significantly $(p<0.05)$ higher level of Clarias. Tilapia $(1: 6)$ than the lower ratios and their monocultures.

\begin{tabular}{|c|c|c|c|c|c|c|c|c|}
\hline \multirow[t]{2}{*}{ Parameter } & \multirow[t]{2}{*}{ Trt 1(0:1) } & \multirow[t]{2}{*}{ Trt 2(1:0) } & \multicolumn{2}{|c|}{ Trt $3(1: 2)$} & \multicolumn{2}{|c|}{ Trt $4(1: 4)$} & \multicolumn{2}{|c|}{ Trt $5(1: 6)$} \\
\hline & & & Clarias & Tilapia & Clarias & Tilapia & Clarias & Tilapia \\
\hline $\operatorname{IMW}(\mathrm{g})$ & $24.85 \pm 0.33(1500)$ & $24.91 \pm 0.39(1500)$ & $24.85 \pm 0.29(496)$ & $24.83 \pm 0.35(997)$ & $24.80 \pm 0.29(300)$ & $24.99 \pm 0.30(1200)$ & $24.80 \pm 0.33(211)$ & $24.98 \pm 0.31(1287)$ \\
\hline FMW $(g)$ & $94.13 \pm 0.78^{\mathrm{h}}$ & $200.29 \pm 1.27^{d}$ & $211.19 \pm 1.16^{\mathrm{c}}$ & $105.4 \pm 0.57^{9}$ & $241.12 \pm 1.12^{\mathrm{b}}$ & $121.17 \pm 1.09^{f}$ & $261.00 \pm 3.24^{\mathrm{a}}$ & $130.64 \pm 3.97^{\mathrm{e}}$ \\
\hline WG(g) & $69.28 \pm 0.85^{\mathrm{h}}$ & $175.38 \pm 1.28^{\mathrm{d}}$ & $186.34 \pm 1.28^{\mathrm{c}}$ & $80.56 \pm 0.69^{9}$ & $216.32 \pm 1.26^{\mathrm{b}}$ & $96.18 \pm 1.17^{f}$ & $236.20 \pm 3.21^{\mathrm{a}}$ & $105.65 \pm 3.95^{\mathrm{e}}$ \\
\hline$\% W G$ & $278.88 \pm 5.92^{h}$ & $704.24 \pm 12.91^{d}$ & $750.03 \pm 12.16^{c}$ & $324.41 \pm 6.55^{g}$ & $872.36 \pm 13.98^{b}$ & $384.91 \pm 7.73^{f}$ & $952.57 \pm 17.90^{\mathrm{a}}$ & $422.86 \pm 16.66^{e}$ \\
\hline SGR(\%) & $0.015 \pm 0.00^{\mathrm{h}}$ & $0.024 \pm 0.00^{\mathrm{d}}$ & $0.025 \pm 0.00^{c}$ & $0.017 \pm 0.00^{9}$ & $0.027 \pm 0.00^{\mathrm{b}}$ & $0.018 \pm 0.00^{f}$ & $0.028 \pm 0.00^{\mathrm{a}}$ & $0.019 \pm 0.00^{\mathrm{e}}$ \\
\hline $\mathrm{K}$ & 1.60 & 2.11 & 2.30 & 0.52 & 2.37 & 1.70 & 1.87 & 1.40 \\
\hline
\end{tabular}

\section{Table3: Growth parameters of $C$. gariepinus and 0 . niloticus in a polyculture system}

IMW = initial mean weight; FMW = final mean weight; WG = weight gain; \%WG= \% weight gain; SGR = specific growth rate; $\mathrm{K}=\mathrm{Condition}$ factor.

*Means in row with same letter are not significantly different $(p>0.05)$.

\section{Variation in weight and length}

Mean weight gain is presented in Table 4. Treatment 5 (1:6) favored higher weight gain of $99.35 \pm 82.24$ and $58.39 \pm 29.99$, for clarias and tilapia, respectively. As such that ratio gave the best performance, while monoculture of both species yielded the lowest weight gain of $69.40 \pm 56.67$ and $50.36 \pm 22.56$ for clarias and tilapia, respectively. For clarias,
Treatment $5(1: 6)$ had the maximum length growth performance $(21.72 \pm 6.56 \mathrm{~cm})$ while the monoculture recorded the minimum $(19.48 \pm 5.67 \mathrm{~cm})$ with more than $2 \mathrm{~cm}$ less than the highest value. The monoculture of tilapia gave the lowest length gain $(12.58 \pm 1.68)$ and was statistically $(P>0.05)$ similar to Treatment $3(1: 2)$; while the highest length gain (13.67 \pm 3.62$)$ for tilapia was recorded in Treatment $5(1: 6)$. 
Table 4: Growth variation in weight and length per treatment during the experiment

\begin{tabular}{lll}
\hline Treatment & Weight $(\mathbf{g})$ & Length $\mathbf{( c m})$ \\
\hline O. niloticus O. niloticus & & \\
Trt 1(0:1) & $50.36 \pm 22.56^{\mathrm{d}}$ & $12.58 \pm 1.68^{\mathrm{c}}$ \\
Trt 3(1:2) & $52.20 \pm 22.26^{\mathrm{c}}$ & $13.10 \pm 1.80^{\mathrm{bc}}$ \\
Trt 4(1:4) & $55.36 \pm 27.82^{\mathrm{b}}$ & $13.17 \pm 4.11^{\mathrm{b}}$ \\
Trt 5(1:6) & $58.39 \pm 29.99^{\mathrm{a}}$ & $13.67 \pm 3.62^{\mathrm{a}}$ \\
C.gariepinus C. gariepinus & & \\
Trt 2(1:0) & $69.40 \pm 56.67^{\mathrm{d}}$ & $19.48 \pm 5.67^{\mathrm{d}}$ \\
Trt 3(1:2) & $75.22 \pm 59.79^{\mathrm{c}}$ & $19.23 \pm 6.74^{\mathrm{c}}$ \\
Trt 4(1:4) & $83.58 \pm 69.14^{\mathrm{b}}$ & $20.99 \pm 6.29^{\mathrm{b}}$ \\
Trt 5(1:6) & $99.35 \pm 82.24^{\mathrm{a}}$ & $21.72 \pm 6.56^{\mathrm{a}}$ \\
\hline
\end{tabular}

Means followed by the same superscript along the column are statistically the same $(P>0.05)$

\section{DISCUSSION}

From the regression parameters and the associated statistics ( $r$ and SE) for the validation of the models, it is evident that there was a strong positive relationship between length and weight. Even though the relationship was curvilinear there were still higher percentages of regression coefficient in all the treatments and between the species. The SE was also low in all the treatments which further validated the log transformed models. Therefore, the models are valid for estimating weight of the fishes from the length measurements without necessarily measuring the weight.

In fish, the condition factor (K) reflects, through its variations, information on the physiological state of the fish in relation to its welfare (Le Cren, 1951). K also gives information when comparing two populations living in certain feeding, density, climate and other conditions; and when following up the degree of feeding activity of a species to verify whether it is making good use of its feeding source (Bagenal and Tesch, 1978). Braga (1986), through other authors, showed that values of the condition factor vary according to season and are influenced by environmental conditions. The same may be occurring

\section{REFERENCES}

Ajayi, T. O. (1982). The age and growth of the Tongue Sole, Cynolossuscanariensis (stend, 1998). In: Proceedings of the 2nd Annual Conference of the Fisheries Society of Nigeria (FISON) New Bush Source. 2: 19: 30-34.

Bagenal, T. B. and Tesch F. W. (1978). In Bagenal and Tesch (ed): Methods for the Assessment of Fish Production in Fresh Waters. $3^{\text {rd }}$ edition. Oxford: Blackwell Scientific Publications. 93-123

Beyer, J. E. (1987).On length-weight relationship.Part 1. Corresponding the mean weight of a given length class. Fishbytes, 5(1): $11-13$.

Boyd, C. E. (1979). Water Quality Management in Warm Water Fish Pond.Auburn University Experimental Station. 359p.

Braga, F. M .S. (1986).Estudo entre o fator de condicaorelaçãpeso/comprimentoparaalgunspeixes marinhos. Rev. Brasil. Biol., 46(2): 339-346.

Diaz, L. S., Roa, A. Garcia, C. B. Acero, A. and Navas, G. (2000). Length-weight relationships of demersal fishes from the upper continental slope off Colombia. The ICLARM Quarterly 23(3): 23-25.

Frota, L. O. Costa, P. A. S. and Braga, A. C. (2004).Length-weight relationship of marine fishes in the environment under study since the concrete tank is influenced by many factors that may affect the well being of both species.

The condition factors 1.87 to 2.37 for Clarias and 0.52 to 1.60 for tilapia obtained in this study were similar with the results from other studies. Bagenal and Tesch (1978) documented 2.9 to 4.8 for mature fresh water fish. Ajayi (1982) reported $\mathrm{K}=0.77$ to 0.81 for Clarotesfilamentosusin lake Oguta; Nwadiaro and Okorie (1985) obtained $\mathrm{K}=0.49$ to 1.48 in Andoni river. Gayando and Pauly (1997) reported that certain factors including, data pulling, sorting into classes, sex, stage of maturity and state of the stomach affect the well being of a fish.

\section{CONCLUSION}

Higher stocking combination of (1:6) should be encouraged to achieve better growth performance and enhanced feed utilization for polyculture practice of Clarias and Tilapia. Further research should be focused on prey-predator relationship of this stocking ratio $(1: 6)$ in concrete tank. There is the need to introduce and encourage the polyculture of Clarias and Tilapia so as to reduce the cost of production.

from the central Brazilian coast.NAGA, the World Fish Center Quarterly, 27(1): 20-26.

Garcia, C. B. Buarte, J. O. Sandoval, N. Von Schiller, D. and Najavas, P. (1998). Length-weight relationships of demersal fishes from the Gulf of Salamanca, Colombia, Fishbyte21:30 - 32.

Gayando, F. C. and D. Pauly, (1997). FAO ICLARM Stock Assessment Tools (FISAT): References Manual, FAO Computerized Information Series (Fisheries) (8): 262

Haimovici, M, and Velasco, G. (2000).Length-weight relationship of marine fishes from southern Brazil. The ICLARM Quarterly 23 (1): 14-16.

King, R. P. (1996). Length-weight relationships of Nigeria freshwater fishes. Naga ICLARM Q. 19 (3): 49 - 52.

Le Cren, E. D., (1951). The length-weight relationship and seasonal cycle in gonad weight and condition in the perch percafluviatilis. Journal Animal Ecology, 20(2): 201-219.

Nwadiaro, C. S. and Okorie, P. U. (1985). Biometric characteristics: Length weight relationships and condition factors in Chrychthysfilamentosus, Pisces, Bagridae from Oguta lake Nigeria, Biol. Afr., 2: 4856. 